\title{
SLC8 family of sodium/calcium exchangers in GtoPdb v.2021.3
}

\author{
Jules Hancox ${ }^{1}$
}

1. University of Bristol, UK

\begin{abstract}
The sodium/calcium exchangers (NCX) use the extracellular sodium concentration to facilitate the extrusion of calcium out of the cell. Alongside the plasma membrane $\mathrm{Ca}^{2+}$-ATPase (PMCA) and sarcoplasmic/endoplasmic reticulum $\mathrm{Ca}^{2+}$-ATPase (SERCA), as well as the sodium/potassium/calcium exchangers (NKCX, SLC24 family), NCX allow recovery of intracellular calcium back to basal levels after cellular stimulation. When intracellular sodium ion levels rise, for example, following depolarisation, these transporters can operate in the reverse direction to allow calcium influx and sodium efflux, as an electrogenic mechanism. Structural modelling suggests the presence of $9 \mathrm{TM}$ segments, with a large intracellular loop between the fifth and sixth TM segments [1].
\end{abstract}

\section{Contents}

This is a citation summary for SLC8 family of sodium/calcium exchangers in the Guide to Pharmacology database (GtoPdb). It exists purely as an adjunct to the database to facilitate the recognition of citations to and from the database by citation analyzers. Readers will almost certainly want to visit the relevant sections of the database which are given here under database links.

GtoPdb is an expert-driven guide to pharmacological targets and the substances that act on them. GtoPdb is a reference work which is most usefully represented as an on-line database. As in any publication this work should be appropriately cited, and the papers it cites should also be recognized. This document provides a citation for the relevant parts of the database, and also provides a reference list for the research cited by those parts. For further details see [2].

Please note that the database version for the citations given in GtoPdb are to the most recent preceding version in which the family or its subfamilies and targets were substantially changed. The links below are to the current version. If you need to consult the cited version, rather than the most recent version, please contact the GtoPdb curators.

\section{Database links}

SLC8 family of sodium/calcium exchangers

https://www.guidetopharmacology.org/GRAC/FamilyDisplayForward?familyId=180

Transporters

NCX1(Sodium/calcium exchanger 1)

https://www.guidetopharmacology.org/GRAC/ObjectDisplayForward?objectId=945

NCX2(Sodium/calcium exchanger 2)

https://www.guidetopharmacology.org/GRAC/ObjectDisplayForward?objectId=946

NCX3(Sodium/calcium exchanger 3)

https://www.guidetopharmacology.org/GRAC/ObjectDisplayForward?objectId=947

\section{References}

1. Alexander SPH, Kelly E, Mathie A, Peters JA, Veale EL, Armstrong JF, Faccenda E, Harding SD, Pawson AJ and Sharman JL et al.. (2019) THE CONCISE GUIDE TO PHARMACOLOGY 2019/20: Transporters. Br J Pharmacol 176 Suppl 1: S397-S493 [PMID:31710713]

2. Buneman P, Christie G, Davies JA, Dimitrellou R, Harding SD, Pawson AJ, Sharman JL and Wu Y. (2020) Why data citation isn't working, and what to do about it Database 2020 
[PMID:32367113]

3. Dong H, Dunn J and Lytton J. (2002) Stoichiometry of the Cardiac Na+/Ca2+ exchanger NCX1.1 measured in transfected HEK cells. Biophys $J$ 82: 1943-52 [PMID:11916852]

4. Iwamoto T and Kita S. (2006) YM-244769, a novel Na+/Ca2+ exchange inhibitor that preferentially inhibits NCX3, efficiently protects against hypoxia/reoxygenation-induced SHSY5Y neuronal cell damage. Mol Pharmacol 70: 2075-83 [PMID:16973719]

5. Jost N, Nagy N, Corici C, Kohajda Z, Horváth A, Acsai K, Biliczki P, Levijoki J, Pollesello P and Koskelainen T et al.. (2013) ORM-10103, a novel specific inhibitor of the $\mathrm{Na}+/ \mathrm{Ca}+$ exchanger, decreases early and delayed afterdepolarizations in the canine heart. Br J Pharmacol 170: 76878 [PMID:23647096]

6. Kohajda Z, Farkas-Morvay N, Jost N, Nagy N, Geramipour A, Horváth A, Varga RS, Hornyik T, Corici C and Acsai K et al.. (2016) The Effect of a Novel Highly Selective Inhibitor of the Sodium/Calcium Exchanger (NCX) on Cardiac Arrhythmias in In Vitro and In Vivo Experiments. PLoS ONE 11: e0166041 [PMID:27832106]

7. Molinaro P, Cantile M, Cuomo O, Secondo A, Pannaccione A, Ambrosino P, Pignataro G, Fiorino F, Severino B and Gatta E et al.. (2013) Neurounina-1, a novel compound that increases $\mathrm{Na}+/ \mathrm{Ca} 2+$ exchanger activity, effectively protects against stroke damage. Mol Pharmacol 83: 142-56 [PMID:23066092]

8. Secondo A, Pignataro G, Ambrosino P, Pannaccione A, Molinaro P, Boscia F, Cantile M, Cuomo O, Esposito A and Sisalli MJ et al.. (2015) Pharmacological characterization of the newly synthesized 5-amino-N-butyl-2-(4-ethoxyphenoxy)-benzamide hydrochloride (BED) as a potent NCX3 inhibitor that worsens anoxic injury in cortical neurons, organotypic hippocampal cultures, and ischemic brain. ACS Chem Neurosci 6: 1361-70 [PMID:25942323]

9. Yamashita K, Watanabe Y, Kita S, Iwamoto T and Kimura J. (2016) Inhibitory effect of YM244769 , a novel $\mathrm{Na}^{+} / \mathrm{Ca}^{2+}$ exchanger inhibitor on $\mathrm{Na}^{+} / \mathrm{Ca}^{2+}$ exchange current in guinea pig cardiac ventricular myocytes. Naunyn Schmiedebergs Arch Pharmacol 389: 1205-1214 [PMID:27480939] 